Original

\title{
Synthesis and characterization of novel $\alpha$-monomers of peptide nucleic acid
}

\author{
Anjali Gupta \\ Department of Chemistry, School of Basic and Applied Sciences, Galgotias University, Greater Noida, U.P., India
}

Received 20 October 2016; accepted 20 January 2017

Available online 27 March 2017

\begin{abstract}
This paper reports the synthesis and characterization of two novel modified $\alpha$-monomers of peptide nucleic acid containing thymine and cytosine nucleobases. These novel monomers have been synthesized by the incorporation of thiol moiety in the side chain of peptide nucleic acid backbone. These novel $\alpha$-monomers have been identified with different spectroscopic techniques, notably infra-red spectroscopy, ${ }^{1} \mathrm{H}$ and ${ }^{13} \mathrm{C}$ nuclear magnetic resonance spectroscopy, supported by mass spectrometry.

(C) 2017 Universidad Nacional Autónoma de México, Centro de Ciencias Aplicadas y Desarrollo Tecnológico. This is an open access article under the CC BY-NC-ND license (http://creativecommons.org/licenses/by-nc-nd/4.0/).
\end{abstract}

Keywords: PNA; Thiol; Cytosine; Thymine; $\alpha$-Monomers

\section{Introduction}

Peptide nucleic acids (PNAs), introduced by Nielsen and coworkers in 1991 are DNA/RNA analogues (Nielsen, Egholm, Berg, \& Buchardt, 1991), whereby $N$-2-aminoethylglycine repeating units replace the sugar-phosphate backbone and the polyamide chain is linked to nucleobases covalently through a carboxymethyl spacer. The attached nucleobases are natural and so through Watson-Crick base pairing are able to bind to complementary DNA/RNA (Egholm et al., 1993). Since the PNA backbone does not contain any charged phosphate group, the absence of electrostatic repulsion gives rise to a stronger binding between PNA/DNA strands than that of DNA/DNA duplex. Consequently, the thermal stability of PNA/DNA duplexes as compared to natural DNA/DNA double helix of the same length is higher. Moreover, unlike DNA/DNA, PNA/DNA duplex is much less affected by medium with high ionic strength medium. It was recently found in lieu of finding relationship of PNA to the origin of life that PNA-like materials are present in cyanobacteria (Banack et al., 2012).

E-mail address: anjali21in@gmail.com

Peer Review under the responsibility of Universidad Nacional Autónoma de México.
The two strands in PNA/DNA hybrid can be fashioned in either parallel or antiparallel orientation but the later mode grabs higher stability because of the achiral backbone of PNA. The stability of the PNA/DNA duplexes is also found to be highly sensitive to the existence of a single mismatched base pair. PNA probes are very sequence-selective and advanced to DNA probes in single-base mismatch recognition. As enzymes are substrate specific, the recognition of neutral backbone of PNA is not easy by either nucleases or proteases, making them potentially resistant to enzymatic degradation and their stability over wide $\mathrm{pH}$ range.

The major drawbacks like poor water solubility, inefficient cellular uptake, self-aggregation and ambiguity in directionality of binding restricts its applications within medicine, diagnostics, molecular biology, etc. One approach to improve cellular uptake is to conjugate PNAs to a wide variety of ligands, such as artificial nucleases, peptides, intercalators or fluorescent reporter groups in order to combine the favourable properties of both entities in a single construct. In most of these conjugates, the attachment of ligand is either to the $C$ - or $N$-terminal end of the PNA. Over the years, a number of backbone-modified PNAs have been prepared to study the effect of introducing chirality, charge or steric bulk on their properties such as hybridization or solubility. The application of a suitably protected thiol modified PNA monomer would give access to a PNA oligomer 
containing a sulfhydryl group suitable for post-assembly conjugation methods (De Koning et al., 2002; De Koning, Van Der Marel, \& Overhand, 2003; De Koning, Filippov, Van der Marel, Van Boom, \& Overhand, 2003; De Koning, Filippov, Van der Marel, Van Boom, \& Overhand, 2004; De Koning et al., 2006; Dose \& Seitz, 2005; Goodwin, Holland, Lay, \& Raney, 1998; Liu \& Balasubramanian, 2000).

\section{Experimental}

\subsection{General procedure}

Melting points were determined on a sulphuric acid bath and are uncorrected. The IR spectra were recorded on a Perkin Elmer model 2000 FT-IR spectrophotometer by making $\mathrm{KBr}$ discs for solid samples and chloroform film for viscous samples. The ${ }^{1} \mathrm{H}$ NMR and ${ }^{13} \mathrm{C}$ NMR spectra were recorded on Bruker Avance 300 spectrometer and Bruker-500 using TMS as internal standard. The chemical shift values are on $\delta$ scale and the coupling constant values $(J)$ are in Hz. EI mass spectra were recorded on Agilent-6210 ESI-TOF. Analytical TLCs were performed on pre-coated Merck silica gel $60 \mathrm{~F}_{254}$ plates with fluorescence indicator; the spots were detected by viewing under UV light or by iodine chamber. Column chromatography was carried out using silica gel (100-200 mesh). U.V. data was recorded on Shimadzu UV2501PC UV-vis spectrophotometer. All other chemicals used were purchased either from S. D. Fine Chemicals, Spectrochem, India or Aldrich Chemical Co., USA and used without further purification.

\subsection{Synthesis of S-p-methoxybenzyl cysteine methylester hydrochloride (2) (Richter, Marsters, \& Gadek, 1994)}

A solution of 4-methoxybenzyl chloride $(5.8 \mathrm{~g}, 37 \mathrm{mmol})$ in dichloromethane $(250 \mathrm{~mL})$ was added dropwise to a solution of L-cysteine $(5 \mathrm{~g}, 37 \mathrm{mmol})$ in trifluoro acetic acid/dichloromethane $(45 \mathrm{~mL} / 250 \mathrm{~mL})$, over a period of $1 \mathrm{~h}$ at $0{ }^{\circ} \mathrm{C}$. The reaction mixture was stirred for $2 \mathrm{~h}$ at room temperature. Then methanol $(150 \mathrm{~mL})$ and water $(500 \mathrm{~mL})$ were added, the layers were separated and the organic layer was re-extracted with water $(100 \mathrm{~mL})$. The aqueous layer was washed with DCM, filtered and solvents were removed in vacuo. The residue was dissolved in water, brought to $\mathrm{pH} 6$ with $10 \% \mathrm{NaHCO}_{3}$ and the product was recrystallized from methanol/water $(3: 1)$. The obtained compound ( $5 \mathrm{~g}$ ) was dissolved in anhydrous methanol $(100 \mathrm{~mL})$ and thionyl chloride $(6 \mathrm{~mL})$ was added dropwise at $0{ }^{\circ} \mathrm{C}$. The reaction mixture was stirred for $3 \mathrm{~h}$ at room temperature. Methanol was then evaporated and the residue was washed with diethyl ether. It was obtained as white solid (80\%); melting point: $80{ }^{\circ} \mathrm{C} ;{ }^{1} \mathrm{H} \mathrm{NMR}\left(\mathrm{CDCl}_{3}, 300 \mathrm{MHz}\right): \delta$ 2.88-2.91 (m, 1H, $\left.\mathrm{H}_{\mathrm{a}}\right), 2.98-3.04\left(\mathrm{~m}, 1 \mathrm{H}, \mathrm{H}_{\mathrm{b}}\right), 3.77(\mathrm{~s}, 2 \mathrm{H}$, H-5), 3.78, 3.82 (2× s, 6H, H-1 and H-10), 4.12 (m, 1H, H3), $6.88(\mathrm{~d}, J=8.7 \mathrm{~Hz}, 2 \mathrm{H}, 2 \times \mathrm{H}-8), 7.28(\mathrm{~d}, J=8.7 \mathrm{~Hz}, 2 \mathrm{H}$, $2 \times \mathrm{H}-7) ;{ }^{13} \mathrm{C} \mathrm{NMR}\left(\mathrm{CDCl}_{3}, 125 \mathrm{MHz}\right): \delta 31.62(\mathrm{C}-4), 35.74$
(C-5), 52.66 (C-1), 53.27 (C-3), 55.97 (C-10), 114.69 (2 × C8), 130.38 (C-6), $131.11(2 \times \mathrm{C}-7), 159.24(\mathrm{C}-9)$ and 169.52 (C-2); IR (KBr) v $v_{\max }$ : $3412.57\left(\mathrm{NH}_{2} \mathrm{str}\right), 2840.36,2637.14$, $1745.85(\mathrm{C}=\mathrm{O}), 1610.29,1581.69,1510.70,1439.71,1324.76$, $1304.90,1247.67,1204.88,1176.08,1150.57,1106.61$, $1059.79,1034.70,995.41,930.54,870.01,830.93,777.10$, 684.89 and $617.09 \mathrm{~cm}^{-1}$; UV (methanol) $\lambda_{\max }: 278 \mathrm{~nm}$; HRMS: $\mathrm{C}_{12} \mathrm{H}_{18} \mathrm{O}_{3} \mathrm{NSCl}[\mathrm{M}]^{+} 291.2902$.

\subsection{Synthesis of $N^{4}$-benzyloxycarbonyl cytosine-1-yl-acetic acid (3) (Dueholm et al., 1994)}

Benzyloxycarbonyl chloride $(5.2 \mathrm{~mL}, 36 \mathrm{mmol})$ was added dropwise to a suspension of cytosine $(2 \mathrm{~g}, 18 \mathrm{mmol})$ in anhydrous pyridine $(100 \mathrm{~mL})$ at $0{ }^{\circ} \mathrm{C}$. The mixture was stirred overnight and, subsequently, the pyridine suspension was evaporated to dryness. Water $(20 \mathrm{~mL})$ was added and $\mathrm{pH}$ was adjusted to 1 with aqueous $4 \mathrm{M} \mathrm{HCl}$. The resultant white precipitate was filtered off, washed with water and partially dried. The wet precipitate was boiled with absolute ethanol $(50 \mathrm{~mL})$ for $10 \mathrm{~min}$, cooled to $10^{\circ} \mathrm{C}$, filtered, washed thoroughly with ether to yield compound 6 in $85 \%$ yield. Ethyl bromoacetate $(0.5 \mathrm{~mL}, 4.1 \mathrm{mmol})$ was then added to a suspension of $N^{4}$-benzyloxycarbonyl cytosine $(1 \mathrm{~g}, 4.1 \mathrm{mmol})$ and $\mathrm{K}_{2} \mathrm{CO}_{3}$ (570 mg, $4.1 \mathrm{mmol}$ ) dissolved in dimethyl formamide $(10 \mathrm{~mL})$. The reaction mixture was stirred overnight at room temperature. The solution was then filtered and evaporated to dryness. The solid residue was treated with water $(4 \mathrm{~mL})$ and $4 \mathrm{M} \mathrm{HCl}(0.2 \mathrm{~mL})$, stirred for $15 \mathrm{~min}$ at $0{ }^{\circ} \mathrm{C}$, filtered and washed with water. Water $(2.5 \mathrm{~mL})$ was added to $N^{4}$-benzyloxycarbonyl cytosine-1-yl-acetic acid ethyl ester $(800 \mathrm{mg}, 2.4 \mathrm{mmol})$ and $2 \mathrm{M} \mathrm{NaOH}(3 \mathrm{~mL})$ and stirred for $2 \mathrm{~h}$. The reaction mixture was cooled to $0{ }^{\circ} \mathrm{C}$ and filtered. The compound was precipitated by the addition of $4 \mathrm{M} \mathrm{HCl}(2 \mathrm{~mL})$. The compound was obtained by recrystallization with methanol as white solid $(60 \%)$; melting point: $272{ }^{\circ} \mathrm{C}$ (Literature value $=266-274{ }^{\circ} \mathrm{C}$ ); ${ }^{1} \mathrm{H}$ NMR $\left(\mathrm{CDCl}_{3}, 300 \mathrm{MHz}\right): \delta 4.54$ (s, 2H, H-14), 5.19 (s, 2H, H-9), 7.06 (d, J=6.8 Hz, 1H, H-5), 7.35-7.40 (m, $\left.5 \mathrm{H}, \mathrm{C}_{6} \mathrm{H}_{5}\right), 8.00(\mathrm{~d}, J=6.6 \mathrm{~Hz}, 1 \mathrm{H}, \mathrm{H}-4) ;{ }^{13} \mathrm{C} \mathrm{NMR}\left(\mathrm{CDCl}_{3}\right.$, $75 \mathrm{MHz}): \delta 50.54$ (C-14), 66.53 (C-9), 94.03 (C-5), 127.95 (2× C-11), 128.17 (C-13), 128.49 (2 × C-12), 135.96 (C-10), 150.42 (C-4), 153.18, 155.03 (C-2 and C-8), 163.31, 169.37 (C-6 and C-15); IR (KBr) $v_{\max }: 3423.87$ (NHCO), 3143.94, 2953.22, 2524.06, 1759.05 (NHCO), 1712.63 (COOH), 1678.72 $(\mathrm{C}=\mathrm{O}), 1629.46,1582.61,1517.58,1454.32,1416.24,1371.21$, 1332.40, 1248.15, 1215.41, 1069.28, 1007.24, 981.10, 901.54, 802.38, 780.06, 738.75, 694.29, 634.79, and $607.86 \mathrm{~cm}^{-1}$; UV (methanol) $\lambda_{\max }$ : $298 \mathrm{~nm}$; HRMS: $\mathrm{C}_{14} \mathrm{H}_{13} \mathrm{O}_{5} \mathrm{~N}_{3}[\mathrm{M}]^{+}$ 303.6239.

\subsection{Synthesis of \\ [(methoxymethylcarbamoyl)-methyl]-carbamic acid tert-butyl ester (4)}

Hydroxybenzotriazole $(7 \mathrm{~g}, 45.7 \mathrm{mmol})$ was added to a solution of boc-glycine $(5 \mathrm{~g}, 28.6 \mathrm{mmol})$ in anhydrous 
dimethyl formamide $(50 \mathrm{~mL})$ followed by the addition of $\mathrm{N}, \mathrm{O}$-dimethylhydroxylamine hydrochloride $(4.5 \mathrm{~g}, 45.7 \mathrm{mmol})$, DIPEA (7.9 mL, $45.7 \mathrm{mmol})$ and DIPC ( $9 \mathrm{~mL}, 57.1 \mathrm{mmol})$. The reaction mixture was stirred overnight at room temperature. The solution was poured into water $(100 \mathrm{~mL})$ and then filtered. The compound was extracted with ethyl acetate $(3 \times$ $40 \mathrm{~mL}$ ). The organic layer was washed with $10 \% \mathrm{KHSO}_{4}, 10 \%$ $\mathrm{NaHCO}_{3}$, water and finally brine. The organic layer was dried with $\mathrm{Na}_{2} \mathrm{SO}_{4}$, filtered and evaporated to a small volume. The product was purified through column chromatography using silica gel (100-200 mesh) in ethyl acetate/petroleum ether (1:1). Compound $\mathbf{4}$ was obtained as white solid (80\%); melting point: $100{ }^{\circ} \mathrm{C} ;{ }^{1} \mathrm{H} \mathrm{NMR}\left(\mathrm{CDCl}_{3}, 300 \mathrm{MHz}\right): \delta 1.46(\mathrm{~s}, 9 \mathrm{H}, \mathrm{H}-1), 3.21$ (s, 3H, H-6), $3.72(\mathrm{~s}, 3 \mathrm{H}, \mathrm{H}-7), 4.09(\mathrm{~s}, 2 \mathrm{H}, \mathrm{H}-4)$ and 5.28 (brs, $1 \mathrm{H}, \mathrm{NH}) ;{ }^{13} \mathrm{C}$ NMR $\left(\mathrm{CDCl}_{3}, 75 \mathrm{MHz}\right): \delta 28.31(3 \times \mathrm{C}-$ 1), 32.37 (C-6), 41.68 (C-4), 61.41 (C-7), 79.60 (C-2), 155.86 (C-3) and 170.18 (C-5). IR (KBr) $v_{\max }: 3333.33(\mathrm{~N}-\mathrm{H}$ str), 3289.71, 3006.83, 2975.75, 2932.75, 1717.43 (COO), 1658.26 (NCO), 1619.57, 1572.61, 1447.43, 1401.80, 1365.72, 1285.99, 1250.32, 1170.30, 1128.03, 1030.63, 985.00, 946.16, 871.52, 807.40, 780.10, 761.18 and $621.05 \mathrm{~cm}^{-1}$; HRMS: $\mathrm{C}_{9} \mathrm{H}_{18} \mathrm{O}_{4} \mathrm{~N}_{2}$ $[\mathrm{M}]^{+} 218.2502$.

\subsection{Synthesis of 2-(bocamino-ethylamino)-3-(4-}

methoxybenzylsulfanyl)-propionic acid methyl ester

(6)

A solution of [(methoxymethylcarbamoyl)-methyl]carbamic acid tert-butyl ester $(3 \mathrm{~g}, 15.9 \mathrm{mmol})$ in anhydrous diethyl ether $(25 \mathrm{~mL})$ was added dropwise in a suspension of $\mathrm{LiAlH}_{4}(726 \mathrm{mg}, 19.2 \mathrm{mmol})$ in diethyl ether $(25 \mathrm{~mL})$ at $-30{ }^{\circ} \mathrm{C}$. The reaction mixture was kept at $0{ }^{\circ} \mathrm{C}$ overnight and then $10 \% \mathrm{KHSO}_{4}$ was added to quench excess of $\mathrm{LiALH}_{4}$. The organic layer was washed with $10 \% \mathrm{NaHCO}_{3}$ and brine. The solution was dried on $\mathrm{Na}_{2} \mathrm{SO}_{4}$ and the solvent was then evaporated to yield crude aldehyde. The aldehyde $(2 \mathrm{~g}$, $12.6 \mathrm{mmol})$ was dissolved in anhydrous methanol $(25 \mathrm{~mL})$ and to it, methyl-2-amino-3-(4-methoxybenzylthio)propanoate hydrochloride $(2,3.7 \mathrm{~g}, 12.6 \mathrm{mmol})$ and $\mathrm{NaCNBH}_{3}(1.5 \mathrm{~g}$, $25.2 \mathrm{mmol}$ ) were added. The reaction mixture was stirred overnight at room temperature. Methanol was evaporated and then the residue was dissolved in ethyl acetate. The organic layer was washed with $10 \% \mathrm{KHSO}_{4}, 10 \% \mathrm{NaHCO}_{3}$ and finally brine. The product was purified through column chromatography using silica gel (100-200 mesh) in ethyl acetate/petroleum ether (1:10). Compound 6 was obtained as viscous oil (40\%); ${ }^{1} \mathrm{H} \mathrm{NMR}\left(\mathrm{CDCl}_{3}, 300 \mathrm{MHz}\right): \delta 1.45$ (s, 9H, H-8), 2.58-2.63 $\left(\mathrm{m}, 1 \mathrm{H}, \mathrm{H}_{\mathrm{b}}\right), 2.67-3.16\left(\mathrm{~m}, 3 \mathrm{H}, \mathrm{H}-4, \mathrm{H}-5\right.$ and $\left.\mathrm{H}_{\mathrm{a}}\right), 3.30-3.39$ (m, 1H, H-2), 3.51 (brs, 1H, NH), 3.69 (s, 2H, H-10), 3.73, $3.79(2 \times \mathrm{s}, 6 \mathrm{H}, \mathrm{H}-9$ and $\mathrm{H}-11), 5.02($ brs $, 1 \mathrm{H}, \mathrm{NH}), 6.85$ $\left(\mathrm{d}, J=8.4 \mathrm{~Hz}, 2 \mathrm{H}, \mathrm{H}-2^{\prime}\right)$ and $7.23\left(\mathrm{~d}, J=8.4 \mathrm{~Hz}, 2 \mathrm{H}, \mathrm{H}-3^{\prime}\right)$; ${ }^{13} \mathrm{C} \mathrm{NMR}\left(\mathrm{CDCl}_{3}, 75 \mathrm{MHz}\right): \delta 28.43(3 \times \mathrm{C}-8), 34.25(\mathrm{C}-3)$, 36.18 (C-10), 47.27 (C-4), 52.11 (C-5), 55.29 (C-11), 60.21 (C-2), 60.55 (C-9), 79.17 (C-7), $113.94\left(2 \times \mathrm{C}^{\prime} 2^{\prime}\right), 129.83$ $\left(\mathrm{C}-1^{\prime}\right), 130.00\left(2 \times \mathrm{C}^{\prime} 3^{\prime}\right), 156.04$ and $158.72\left(\mathrm{C}-4^{\prime}\right.$ and $\left.\mathrm{C}-6\right)$,
$174.03(\mathrm{C}-1) . \mathrm{IR}(\mathrm{KBr}) v_{\max }: 3357.90(\mathrm{~N}-\mathrm{H}$ str), 2976.13, $1735.99,1708.90,1610.44,1512.65,1459.59,1390.88$, $1366.35,1249.95,1173.22,1035.08,832.51$ and $775.30 \mathrm{~cm}^{-1}$. UV (methanol) $\lambda_{\max }: 279 \mathrm{~nm}$. HRMS: $\mathrm{C}_{19} \mathrm{H}_{30} \mathrm{O}_{5} \mathrm{~N}_{2} \mathrm{~S}[\mathrm{M}]^{+}$ 398.8868 .

2.6. General procedure for synthesis of 2-[\{2-(Base-1-yl)acetyl\}boc-aminoethylamino]-3-(4-methoxybenzyl sulfanyl)-propionic acid methyl ester (7 and 8 )

2-(2-Bocamino-ethylamino)-3-(4-methoxybenzylsulfanyl)propionic acid methyl ester $(1 \mathrm{~g}, 2.4 \mathrm{mmol})$ was dissolved in anhydrous dimethyl formamide $(15 \mathrm{~mL})$. At $0{ }^{\circ} \mathrm{C}$, base-1-yl-acetic acid (3.6 mmol) and 1-ethyl-3-(3dimethylaminopropyl)carbodiimide hydrochloride (EDC) (700 $\mathrm{mg}, 3.6 \mathrm{mmol})$ were added. The reaction mixture was stirred overnight and then added to ice cold water $(10 \mathrm{~mL})$. The compound was extracted with chloroform and the organic layer was washed with $10 \% \mathrm{NaHCO}_{3}$ and brine. The product was obtained through column chromatography using silica gel (100-200 mesh) in ethyl acetate/petroleum ether (3:2).

\subsection{2-[\{2-(Thymin-1-yl)-acetyl $\}$ boc-aminoethylamino]-3- (4-methoxybenzylsulfanyl)-propionic acid methyl ester (7)}

Compound 7 was obtained as white solid (70\%); melting point: $68-70{ }^{\circ} \mathrm{C} ;{ }^{1} \mathrm{H}$ NMR (two rotamers, $\mathrm{CDCl}_{3}, 300 \mathrm{MHz}$ ): $\delta 1.45(\mathrm{~s}, 9 \mathrm{H}, \mathrm{H}-9), 1.91(\mathrm{~s}, 3 \mathrm{H}, \mathrm{H}-12), 3.09-3.13(\mathrm{~m}, 5 \mathrm{H}$, H-6, H-7 and H-2), 3.69-3.79 (m, 10H, H-2', H-4, H-5 and $\mathrm{H}-15), 4.45-4.61\left(\mathrm{~m}, 2 \mathrm{H}, \mathrm{H}_{\mathrm{a}}\right.$ and $\left.\mathrm{H}_{\mathrm{b}}\right), 5.30$ (brs, $\left.1 \mathrm{H}, \mathrm{NHBoc}\right)$, $6.85\left(\mathrm{~m}, 3 \mathrm{H}, \mathrm{H}-2^{\prime \prime}\right.$ and $\left.\mathrm{H}-10\right), 7.22\left(\mathrm{~d}, J=8.1 \mathrm{~Hz}, 2 \mathrm{H}, \mathrm{H}-3^{\prime \prime}\right)$; ${ }^{13} \mathrm{C}$ NMR $\left(\mathrm{CDCl}_{3}, 75 \mathrm{MHz}\right): \delta 12.35(\mathrm{C}-12), 28.40(3 \times \mathrm{C}-9)$, 30.53 (C-3), 36.68 (C-4), 38.56 (C-6), 48.13 (C-7), 48.56 (C-2'), 52.85 (C-5), 55.31 (C-15), 61.06 (C-2), 80.00 (C-8), 110.67 (C$11), 114.05\left(2 \times \mathrm{C}-2^{\prime \prime}\right), 130.02\left(2 \times \mathrm{C}-3^{\prime \prime}, \mathrm{C}-1^{\prime \prime}\right), 140.79(\mathrm{C}-13)$, $150.73,156.87$ and 158.85 (C-4", C-14 and C-16), 163.98 (C10), 167.22 and $170.17\left(\mathrm{C}-1\right.$ and $\left.\mathrm{C}-1^{\prime}\right)$; IR (KBr) $v_{\max }: 3343.66$ (N-H str), 3201.56, 3010.30, 2838.28, 1680.61 (COO), 1610.92, $1512.24,1465.46,1368.35,1302.84,1247.87,1174.14$, $1107.92,1032.54,965.46,834.78,755.41$ and $667.00 \mathrm{~cm}^{-1} ; \mathrm{UV}$ (methanol) $\lambda_{\max }: 269 \mathrm{~nm}$; HRMS: $\mathrm{C}_{26} \mathrm{H}_{36} \mathrm{O}_{8} \mathrm{~N}_{4} \mathrm{~S}[\mathrm{M}+\mathrm{H}+\mathrm{Na}]^{+}$ 587.9988 .

\subsection{2-[\{2-(N4-Cbz-cytosin-1-yl)-acetyl $\}$ boc- aminoethylamino]-3-(4-methoxybenzylsulfanyl)-propionic acid methyl ester $(\mathbf{8})$}

Compound 8 was obtained as white solid (60\%); melting point: $66-68{ }^{\circ} \mathrm{C} ;{ }^{1} \mathrm{H}$ NMR (two rotamers, $\mathrm{CDCl}_{3}, 300 \mathrm{MHz}$ ): 
$\delta 1.47(\mathrm{~s}, 9 \mathrm{H}, \mathrm{H}-10), 3.02-3.38(\mathrm{~m}, 5 \mathrm{H}, \mathrm{H}-2, \mathrm{H}-6$ and $\mathrm{H}-$ 7), 3.59-3.83 (m, 10H, H-2', H-4, H-11 and H-5), 4.59-4.88, $\left(\mathrm{m}, 2 \mathrm{H}, \mathrm{H}_{\mathrm{a}}\right.$ and $\left.\mathrm{H}_{\mathrm{b}}\right), 5.26(\mathrm{~s}, 3 \mathrm{H}, \mathrm{H}-17), 5.54($ brs, $1 \mathrm{H}$, NHBoc), $6.88\left(\mathrm{~d}, J=8.1 \mathrm{~Hz}, 2 \mathrm{H}, \mathrm{H}-2^{\prime \prime}\right), 7.26(\mathrm{~d}, J=7.8 \mathrm{~Hz}$, $\left.2 \mathrm{H}, \mathrm{H}-3^{\prime \prime}\right), 7.31-7.51$ (m, 7H, Ar-Cbz, $\mathrm{H}-12$ and $\mathrm{H}-13$ ); ${ }^{13} \mathrm{C}$ NMR (Acetone- $\left.d_{6}, 75 \mathrm{MHz}\right): \delta 28.62(3 \times \mathrm{C}-10), 31.16(\mathrm{C}-$ 3), 36.33 (C-4), 39.82 (C-6), 49.24 (C-7), 50.85 (C-2'), 52.57 (C-11), 55.54 (C-5), 61.49 (C-2), 67.83 (C-17), 79.29 (C9), 94.67 (C-13), $114.77\left(2 \times \mathrm{C}-2^{\prime \prime}\right), 128.87,129.04,129.36$ (C-19, C-20 and C-21), $131.15\left(2 \times \mathrm{C}-3^{\prime \prime}\right), 132.44\left(\mathrm{C}-1^{\prime \prime}\right)$, 137.08 (C-18), 151.35 (C-12), 153.91, 156.90, 158.15 and 159.78 (C-4", C-8, C-15 and C-16), 164.12, 168.39 and $170.90\left(\mathrm{C}-1, \mathrm{C}-1^{\prime}\right.$ and $\left.\mathrm{C}-14\right)$; IR $(\mathrm{KBr}) v_{\max }: 3407.37(\mathrm{~N}-$ H str), 3015.79, 2850.36, 1744.75 (COO), 1664.33, 1630.62, $1561.35,1508.96,1454.23,1369.11,1249.01,1214.04$, $1062.19,1034.00,1002.03,755.25,698.11$ and $667.21 \mathrm{~cm}^{-1}$. UV (methanol) $\lambda_{\max }: 302 \mathrm{~nm}$; HRMS: $\mathrm{C}_{33} \mathrm{H}_{41} \mathrm{O}_{9} \mathrm{~N}_{5} \mathrm{~S}[\mathrm{M}+\mathrm{H}]^{+}$ 684.1031

2.9. General procedure for synthesis of 2-[\{2-(base-1-yl)acetyl\}boc-aminoethylamino]-3-(4-methoxybenzyl sulfanyl)-propionic acid (9 and 10)

2-[\{2-(Base-1-yl)-acetyl $\}$ boc-aminoethylamino]-3-(4methoxybenzylsulfanyl)-propionic acid methyl ester $(500 \mathrm{mg})$ was dissolved in methanol $(3 \mathrm{~mL})$ and $4 \mathrm{M} \mathrm{LiOH}$ solution $(2 \mathrm{~mL})$ was added to it. The reaction mixture was stirred overnight and then methanol was evaporated. The mixture was acidified to $\mathrm{pH} 5$ by the addition of $2 \mathrm{M} \mathrm{HCl}$ solution. The precipitate was then filtered and washed with ether.

\subsection{2-[\{2-(Thymin-1-yl)-acetyl\}boc-aminoethylamino]- 3-(4-methoxybenzylsulfanyl)-propionic acid}

(9)

Compound 9 was obtained as semisolid $(60 \%) ;{ }^{1} \mathrm{H}$ NMR (two rotamers, Acetone- $\left.d_{6}, 300 \mathrm{MHz}\right): \delta 1.42(\mathrm{~s}, 9 \mathrm{H}, \mathrm{H}-9), 1.81(\mathrm{~s}$, $3 \mathrm{H}, \mathrm{H}-12)$, 3.30-3.50 (m, 5H, H-2, H-6, and $\mathrm{H}-7)$, 3.71-3.77 $\left(\mathrm{m}, 7 \mathrm{H}, \mathrm{H}-2^{\prime}, \mathrm{H}-4\right.$ and $\left.\mathrm{H}-5\right), 4.29($ brs $, 1 \mathrm{H}, \mathrm{NH}), 4.66-4.83(\mathrm{~m}$, $2 \mathrm{H}, \mathrm{H}_{\mathrm{a}}$ and $\left.\mathrm{H}_{\mathrm{b}}\right), 6.86\left(\mathrm{~d}, J=8.7 \mathrm{~Hz}, 2 \mathrm{H}, \mathrm{H}-2^{\prime \prime}\right)$ and $7.25-7.29$ $\left(\mathrm{m}, 3 \mathrm{H}, 2 \times \mathrm{H}-3^{\prime \prime}\right.$ and $\left.\mathrm{H}-10\right) ;{ }^{13} \mathrm{C}$ NMR (Acetone- $d_{6}, 75 \mathrm{MHz}$ ): $\delta 13.35$ (C-12), $29.70(3 \times$ C-9), 31.24 (C-3), $36.36(\mathrm{C}-4), 39.76$ (C-6), 49.01 (C-7), 49.19 (C-2'), 55.54 (C-5), 61.39 (C-2), 79.37 (C-8), $109.83(\mathrm{C}-11), 114.78\left(2 \times \mathrm{C}-2^{\prime \prime}\right), 114.85\left(\mathrm{C}-1^{\prime \prime}\right), 131.04$ $\left(2 \times \mathrm{C}-3^{\prime \prime}\right), 142.62(\mathrm{C}-13), 151.91,153.46$ and $156.86\left(\mathrm{C}-4^{\prime \prime}\right.$, $\mathrm{C}-14$ and $\mathrm{C}-15), 159.77$ (C-10), 164.86 and 168.40 (C-1 and $\left.\mathrm{C}-1^{\prime}\right)$; IR (KBr) $v_{\max }: 3422.33(\mathrm{~N}-\mathrm{H}$ and $\mathrm{COOH}), 2974.78$, $2930.22,1675.98,1512.18,1465.01,1367.77,1248.77$, $1171.39,1031.70,964.96,835.12,780.41$, and $552.03 \mathrm{~cm}^{-1}$; $\mathrm{UV}$ (methanol) $\lambda_{\text {max }}: 268 \mathrm{~nm}$; HRMS: $\mathrm{C}_{25} \mathrm{H}_{34} \mathrm{O}_{8} \mathrm{~N}_{4} \mathrm{~S}[\mathrm{M}+\mathrm{Na}]^{+}$ 573.4542
2.11. 2- $\left[\left\{2-\left(N^{4}-\right.\right.\right.$ Cbzcytosin-1-yl $)-$ acetyl $\}$ Bocaminoethylamino]-3-(4-methoxybenzylsulfanyl)-propionic acid (10)<smiles>COc1ccc(CSC(C)(C)C(C(=O)O)N(CCNC(=O)OC(C)(C)C)C(=O)Cn2ccc(NC(=O)OCc3ccccc3)nc2=O)cc1</smiles>

Compound 10 was obtained as white semisolid $(55 \%) ;{ }^{1} \mathrm{H}$ NMR (two rotamers, $\mathrm{CDCl}_{3}, 300 \mathrm{MHz}$ ): $\delta 1.43(\mathrm{~s}, 9 \mathrm{H}, \mathrm{H}-$ 10), 2.95-3.59 (m, 5H, H-2, H-6 and H-7), 3.64 (s, 2H, H-4), $3.72-3.79\left(\mathrm{~m}, 5 \mathrm{H}, \mathrm{H}-2^{\prime}\right.$ and $\left.\mathrm{H}-5\right), 4.85-4.96\left(\mathrm{~m}, 2 \mathrm{H}, \mathrm{H}_{\mathrm{a}}\right.$ and $\left.\mathrm{H}_{\mathrm{b}}\right)$, 5.24 (s, 3H, H-16), 6.21 (brs, 1H, NHBoc), 6.87 (d, $J=8.7 \mathrm{~Hz}$, $\left.2 \mathrm{H}, \mathrm{H}-2^{\prime \prime}\right), 7.28\left(\mathrm{~d}, J=8.4 \mathrm{~Hz}, 2 \mathrm{H}, \mathrm{H}-3^{\prime \prime}\right), 7.33-7.47$ (m, 6H, Ar$\mathrm{Cbz}, \mathrm{H}-12), 7.87$ (d, $1 \mathrm{H}, J=7.2 \mathrm{~Hz}, \mathrm{H}-11) ;{ }^{13} \mathrm{C} \mathrm{NMR}\left(\mathrm{CDCl}_{3}\right.$, $75 \mathrm{MHz}): \delta 28.43$ (3 × C-10), 30.51 (C-3), 36.61 (C-4), 38.82 (C-6), 49.06 (C-7), 49.73 (C-2'), 55.32 (C-5), 61.15 (C-2), 67.89 (C-16), 79.95 (C-9), 94.99 (C-12), $114.02\left(2 \times \mathrm{C}-2^{\prime \prime}\right)$, 128.26-128.69 (C-18 - C-20), $130.10\left(2 \times \mathrm{C}-3^{\prime \prime}\right), 131.53$ (C$\left.1^{\prime \prime}\right), 135.06$ (C-17), 149.59 (C-11), 152.35, 155.37 and 155.99 (C-4", C-8 and C-14), 158.78, 162.91, 167.09 and 170.20 (C$1, \mathrm{C}-1^{\prime}, \mathrm{C}-13$ and $\left.\mathrm{C}-15\right)$; IR $\left(\mathrm{CHCl}_{3}\right) v_{\max }: 3423.82(\mathrm{~N}-\mathrm{H}$ str), 2927.79, 2851.54, $1700.69(\mathrm{COOH}), 1686.74,1655.94$, $1511.48,1457.34,1367.83,1250.34,1211.18,1174.83$, 1032.25, 833.56, 774.82 and $609.79 \mathrm{~cm}^{-1}$; UV (methanol) $\lambda_{\max }$ : $310 \mathrm{~nm}$; HRMS: Calculated for $\mathrm{C}_{32} \mathrm{H}_{37} \mathrm{O}_{9} \mathrm{~N}_{5} \mathrm{~S}[\mathrm{M}]^{+}$ 667.4619 .

\section{Results and discussion}

The synthesis of the monomer started with boc-glycine and $\mathrm{N}, \mathrm{O}$-dimethylhydroxylamine, which was converted to its Weinreb amide, [(methoxymethylcarbamoyl)-methyl]-carbamic acid tert-butyl ester (4) in about $80 \%$ yield. In its IR spectrum, it showed characteristic peaks at $3333 \mathrm{~cm}^{-1}$ that describe $\mathrm{N}-\mathrm{H}$ stretching. In the ${ }^{1} \mathrm{H}$ NMR spectrum (Fig. 1), a characteristic singlet at $\delta 1.46$ for nine protons and corresponding peaks in ${ }^{13} \mathrm{C}$ NMR at $\delta 28.31,79.60$ and 155.86 confirm the tertbutyloxycarbonyl (boc) group. Two singlets in ${ }^{1} \mathrm{H}$ NMR at $\delta$ 3.21 and $\delta 3.72$ each integrating for three protons were due to methyl and methoxy groups attached to nitrogen, respectively. A 


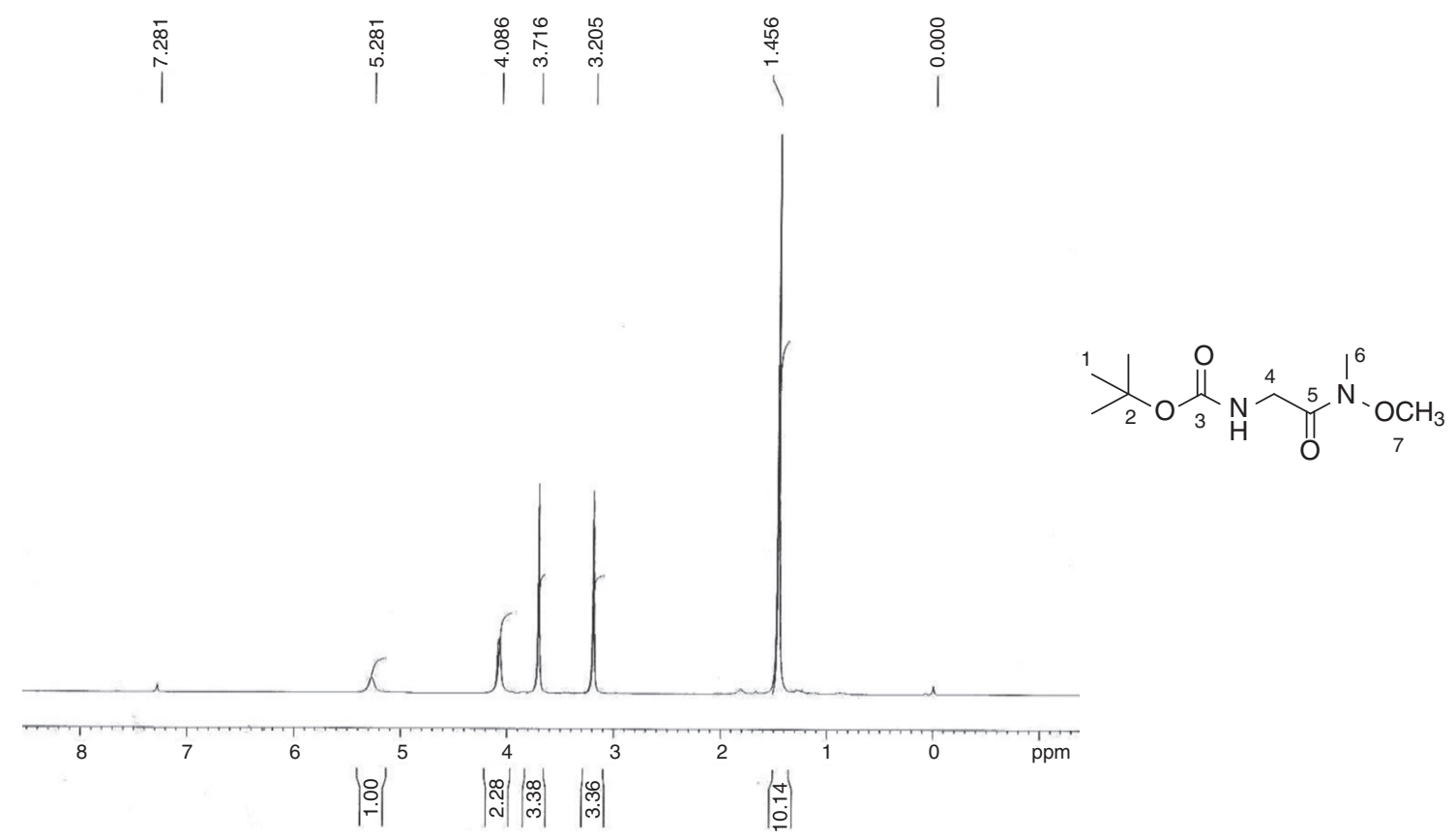

Fig. 1. ${ }^{1} \mathrm{H}$ NMR spectra of [(Methoxymethylcarbamoyl)-methyl]-carbamic acid tert-butyl ester (4).

singlet corresponding to glycine methylene group was observed at $\delta 4.09$.

Reduction of Weinreb amide with lithium aluminium hydride yields an aldehyde, (2-oxo-ethyl)-carbamic acid tert-butyl ester (5) and its subsequent reductive amination with methyl-2amino-3-(4-methoxybenzylthio)propanoate hydrochloride (2) yields PNA backbone that contains ligation handle, sulfhydryl group at $\alpha$-position. Compound (6) was obtained in $40 \%$ yield as colourless oil. In its IR spectrum, it showed characteristic peaks at $3357 \mathrm{~cm}^{-1}$ that describe $\mathrm{N}-\mathrm{H}$ stretching. In the ${ }^{1} \mathrm{H} \mathrm{NMR}$ spectrum (Fig. 2), a characteristic singlet at $\delta 1.45$ for nine protons was observed for the three methyl groups of boc and the corresponding carbons in ${ }^{13} \mathrm{C} \mathrm{NMR}$ appeared at $\delta 28.43$ while the boc tertiary carbon appeared at $\delta 79.17$. A multiplet in the range $\delta 2.58-2.63$ was assigned to one of the diastereotopic proton $\mathrm{H}_{\mathrm{b}}$. Another multiplet in the range $\delta 2.67-3.16$ was observed for another diastereotopic proton $\mathrm{H}_{\mathrm{a}}$ and two methylene groups $(\mathrm{H}-$ 4 and $\mathrm{H}-5$ ) of ethylene diamine unit. The corresponding carbons for C-4 and C-5 appeared at $\delta 47.27$ and $\delta 52.11$, respectively in ${ }^{13} \mathrm{C}$ NMR. The chiral centre of cysteine, i.e. H-2 appeared downfield as multiplet in the range $\delta 3.30-3.39$ because of the attached thiol linkage. A singlet for methylene group attached with the sulfhydryl group was observed at $\delta 3.69$, while two singlets corresponding to two methoxy groups were observed at $\delta 3.73$ and $\delta 3.79$ that explain the incorporation of suitably protected cysteine in the backbone at $\alpha$-position. Two ortho coupled doublets (two protons each) at $\delta 6.85(J=8.4 \mathrm{~Hz})$ and $\delta 7.23(J=8.4 \mathrm{~Hz})$ were assigned to the aromatic protons of $S$-benzyl group. In ${ }^{13} \mathrm{C}$ NMR spectrum, peaks at $\delta 34.25$ and $\delta 36.18$ were identified for two methylene groups, C-3 and C-10 attached to the thiol group. The two methoxy groups were observed at $\delta 55.29$ and $\delta 60.55$, while the carbonyl of the ester group was observed at $\delta$ 174.03 .
The thiol group of cysteine was protected using $p$-methoxy benzyl chloride followed by its esterification in methanol and thionyl chloride to obtain $S$ - $p$-methoxy benzyl cysteine methylester hydrochloride in about $80 \%$ yield (Scheme 1 ). In its IR spectrum, it showed a characteristic peak at $3412 \mathrm{~cm}^{-1}$ corresponding to $\mathrm{N}-\mathrm{H}$ stretching. A peak at $1745 \mathrm{~cm}^{-1}$ explains the presence of ester linkage. In the UV spectrum, it showed absorption at $\lambda_{\max } 278 \mathrm{~nm}$. In the ${ }^{1} \mathrm{H}$ NMR spectrum, two multiplets were observed in the range $\delta 2.88-2.91$ and $\delta 2.98-3.04$ for diastereotopic protons $\mathrm{H}_{\mathrm{a}}$ and $\mathrm{H}_{\mathrm{b}}$ respectively, because of vicinal as well as geminal coupling. A singlet was observed at $\delta 3.77$ for methylene protons of the benzyl group as well as two singlets were observed at $\delta 3.78$ and $\delta 3.82$ which accounts for the presence of two methoxy groups. A downfield triplet for the chiral proton of cysteine (H-3) was observed at $\delta 4.12$ because of the presence of amino and ester functionalities in neighbouring positions. Two doublets at $\delta 6.88(\mathrm{~J}=8.7 \mathrm{~Hz})$ and $\delta 7.28(J=8.7 \mathrm{~Hz})$ each integrating for two protons was assigned for aromatic protons and this was in accordance with the 1,4disubstitution of the phenyl group. In the ${ }^{13} \mathrm{C} N M R$ spectrum, characteristic peaks corresponding to carbons of cysteine moiety were observed at $\delta 31.62(\mathrm{C}-4)$ and $\delta 53.27$ (C-3). The two methoxy carbons appeared at $\delta 52.66$ and $\delta 55.97$, while the carbonyl carbon was observed at $\delta 169.52$.

The final steps to the target PNA building block comprised the EDC-mediated installation of the suitably protected nucleobase followed by saponification using $4 \mathrm{M}$ lithium hydroxide in methanol (Scheme 3). Nucleobases thymine and cytosine were incorporated via methylene bridges. Since thymine does not contain any side chain which is to be protected so thymine acetic acid was used as such but the exocyclic amino group of cytosine was protected to prevent self-condensation. The amino group of nucleobase cytosine was protected using the benzyloxycarbonyl 


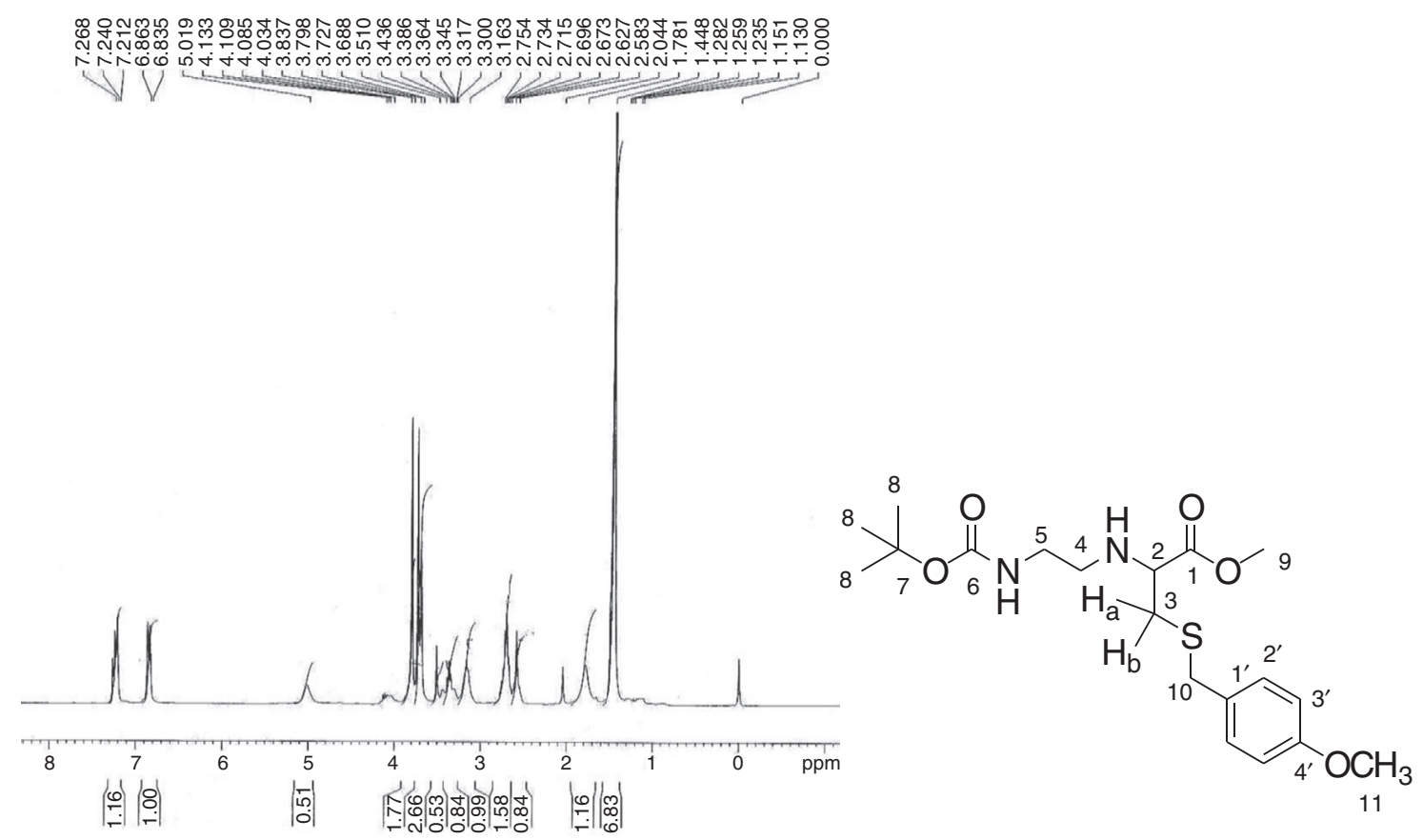

Fig. 2. ${ }^{1} \mathrm{H}$ NMR spectra of 2-(Bocamino-ethylamino)-3-(4-methoxybenzylsulfanyl)-propionic acid methyl ester (6).<smiles>COc1ccc(CSCC(N)C(=O)O)cc1</smiles><smiles>COC(=O)C(N)CSCc1ccc(OC)cc1</smiles>

Scheme 1. Synthesis of $S$-p-Methoxybenzyl cysteine methylester hydrochloride.

$(\mathrm{Cbz})$ group and then introduction of acetic acid was carried out for coupling on backbone (Scheme 2).

In the ${ }^{1} \mathrm{H}$ NMR spectrum for 2-[\{2-( $N^{4}-$ Cbz-cytosin-1-yl $)$ acetyl\}Boc-aminoethylamino]-3-(4-methoxybenzyl sulfanyl)propionic acid methyl ester (8) (Fig. 3), a characteristic singlet for nine protons for three methyl groups at $\delta 1.47$ and corresponding peaks in ${ }^{13} \mathrm{C}$ NMR, at $\delta 28.62$ along with $\delta 79.29$ were due to the presence of the boc group. The methylene groups of ethylene diamine backbone (H-6 and H-7) and proton present at the chiral centre of cysteine moiety $(\mathrm{H}-2)$ appeared in the range $\delta 3.02-3.38$. The two diastereotopic protons of cysteine $\mathrm{H}_{\mathrm{a}}$ and $\mathrm{H}_{\mathrm{b}}$ appeared as a multiplet in the range of $\delta 4.59-4.88$. The methylene protons of the benzyloxy group $(\mathrm{H}-17)$ appeared at $\delta 5.26$ and a multiplet for the aromatic protons of the $\mathrm{Cbz}$ group along with the aromatic protons of cytosine $(\mathrm{H}-12$ and $\mathrm{H}-13)$ appeared in the range $\delta 7.31-7.51$. That confirms the presence of Cbz-protected cytosine moiety. In the ${ }^{13} \mathrm{C}$ NMR spectrum, peaks for two methylene carbons of ethylene diamine moiety were observed at $\delta 39.82$ and 49.24 for C- 6 and C-7, respectively. Characteristic peaks for cytosine were observed at $\delta 94.67(\mathrm{C}-13)$ and $\delta 151.35(\mathrm{C}-12)$. The amide carbonyl $\left(\mathrm{C}-1^{\prime}\right)$ and ester carbonyl (C-1) appeared in the range $\delta 164.12-170.90$. In HRMS, the $[\mathrm{M}+\mathrm{H}]^{\bullet+}$ peak was observed at 684.1031 having a molecular formula $\mathrm{C}_{33} \mathrm{H}_{41} \mathrm{O}_{9} \mathrm{~N}_{5} \mathrm{~S}$ (calculated value: 684.0625).

In the ${ }^{1} \mathrm{H}$ NMR spectrum for 2-[\{2-(Thymin-1-yl)acetyl\}boc-aminoethylamino]-3-(4-methoxybenzylsulfanyl)propionic acid (9) (Fig. 4), a characteristic singlet for nine protons at $\delta 1.42$ explains the presence of the boc group. A 

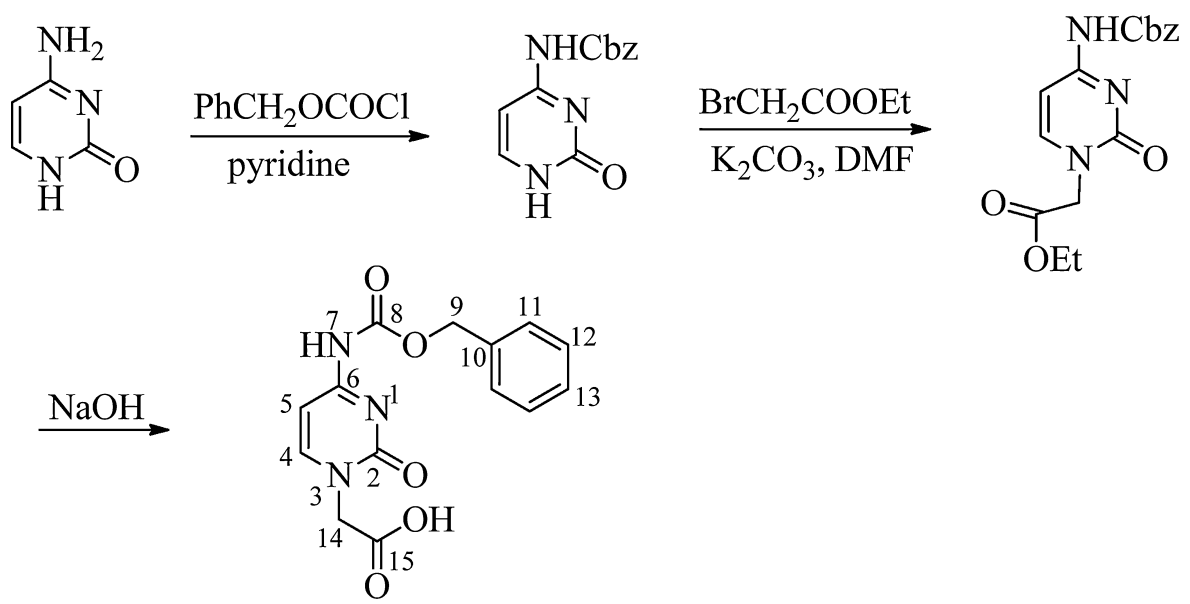

3

Scheme 2. Synthesis of base acetic acid.
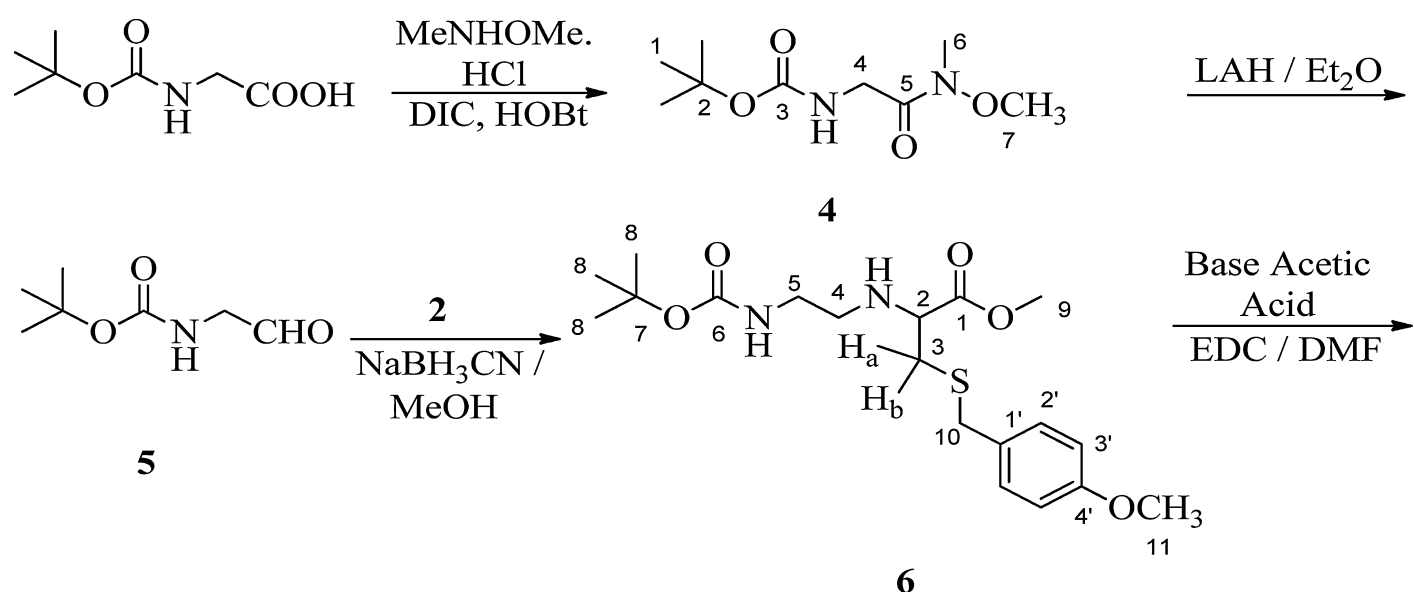<smiles>[B]CC(=O)N(CCNC(=O)OC(C)(C)C)C(CSCc1ccc(OC)cc1)C(=O)OCC(C)(C)O</smiles>

$7 \mathrm{~B}=$ Thymine

$8 \mathrm{~B}=$ Cbz-cytosine
$9 \mathrm{~B}=$ Thymine

$10 \mathrm{~B}=$ Cbz-cytosine

Scheme 3. Synthesis of thiol-modified PNA monomer containing pyrimidine nucleobases.

singlet for the methyl group at $\delta 1.81$ for three protons was assigned to the thymine methyl group. The thymine ring proton (H-10) appeared as multiplet along with aromatic protons $\left(\mathrm{H}-3^{\prime \prime}\right)$ in the range $\delta 7.25-7.29$. As multiplets in the range $\delta$ $3.30-3.50$, the methylene groups of ethylene diamine backbone
(H-6 and H-7) appear along with the proton present at the chiral centre of cysteine moiety $(\mathrm{H}-2)$. In the ${ }^{13} \mathrm{C}$ NMR spectrum (Fig. 5), peaks for two methylene carbons of ethylene diamine moiety were observed at $\delta 39.76$ and 49.01. Characteristic peaks for the methyl group of thymine was observed at $\delta 13.35$. The 

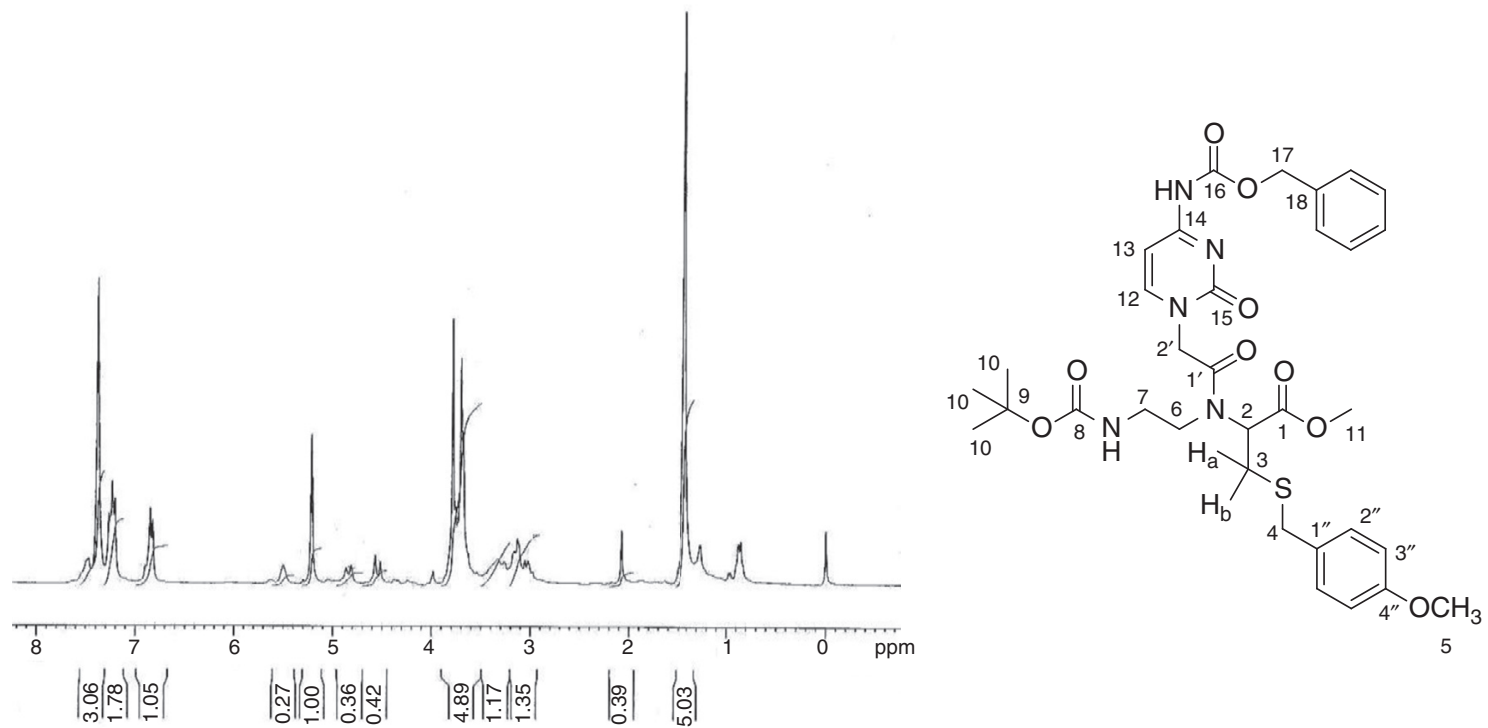

Fig. 3. ${ }^{1} \mathrm{H}$ NMR spectra of 2-[\{2-( $N^{4}-$ Cbz-cytosin-1-yl)-acetyl $\}$ Boc-aminoethylamino]-3-(4-methoxybenzyl sulfanyl)-propionic acid methyl ester (8).

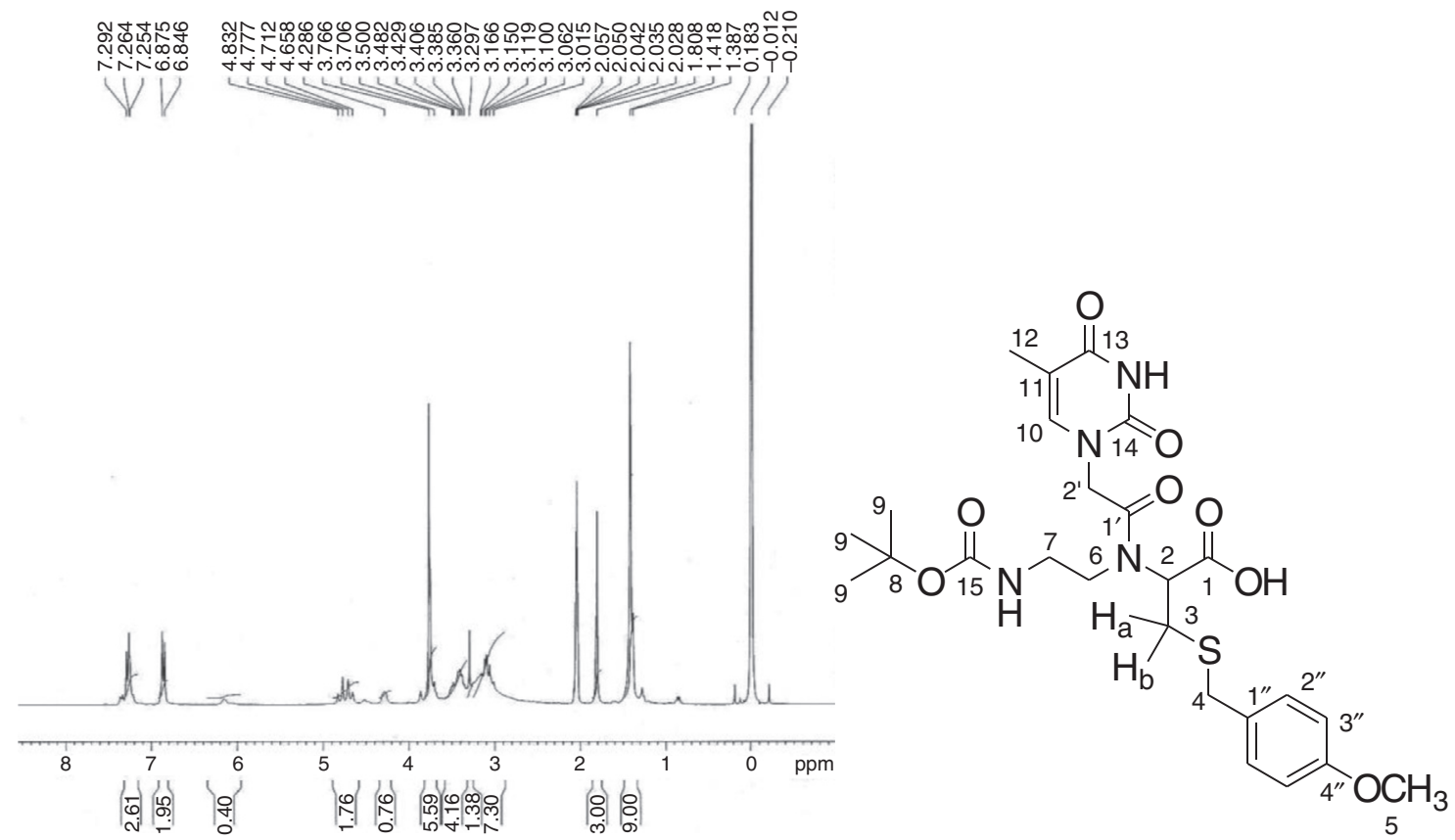

Fig. 4. ${ }^{1}$ H NMR spectra of 2-[\{2-(Thymin-1-yl)-acetyl\}boc-aminoethylamino]-3-(4-methoxybenzylsulfanyl)-propionic acid (9).

amide carbonyl (C-1') and acid carbonyl (C-1) were assigned in the range of $\delta 164.86-168.40$. The identity of the modified PNA monomers was confirmed by NMR, IR and mass spectrometry.

Combining the use of the $p$-methoxy benzyl group for thiol protection and the Boc group for terminal $\mathrm{NH}_{2}$ has led to the simple preparation of a dual labelled PNA monomer which may be used as a diagnostic tool for biomedical studies. The synthesis of a new mercaptomethyl-modified PNA monomer allows the application of native chemical ligation-like fragment coupling reactions without detriment to backbone geometry. It was shown that the DNA affinity of the PNA ligation products is as high as the affinity of unmodified PNA obtained by linear solid-phase synthesis.

While many PNA backbone modifications have shown the deleterious effect on PNA hybridization, it was observed that the addition of the mercaptomethyl group in PNA ligation products hardly influences the stability of a PNA/RNA duplex. This convergent approach may find applications in 


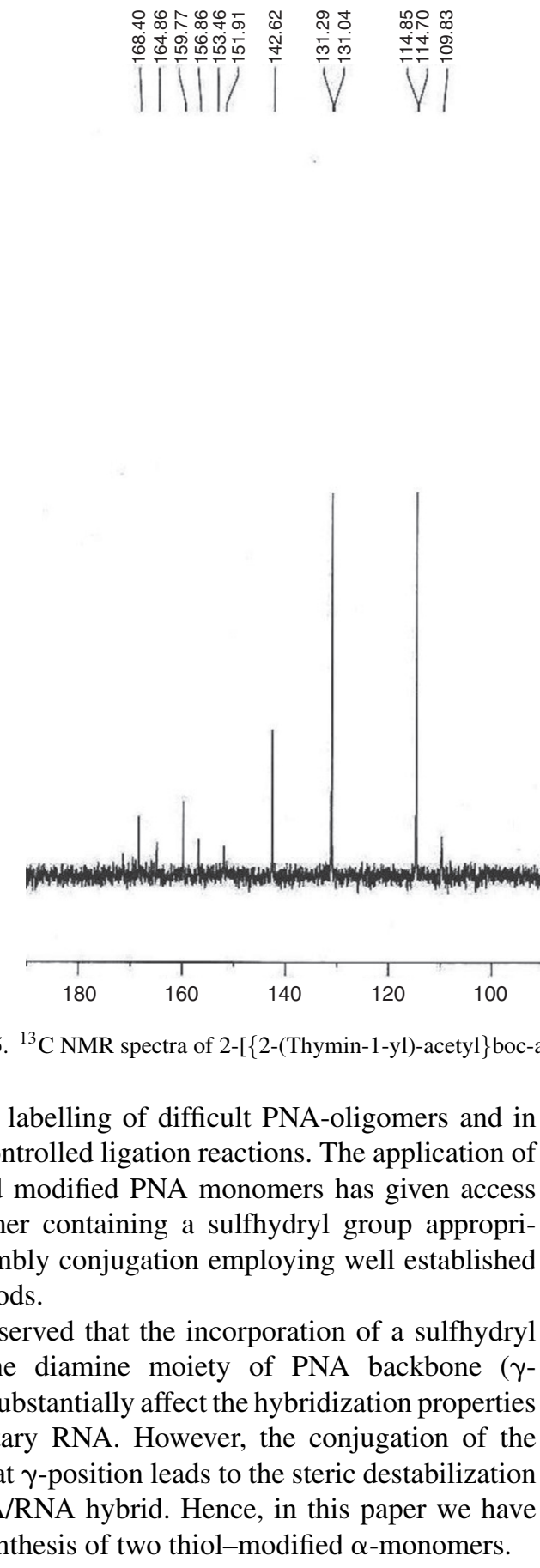

the synthesis and labelling of difficult PNA-oligomers and in DNA-template-controlled ligation reactions. The application of suitably protected modified PNA monomers has given access to a PNA oligomer containing a sulfhydryl group appropriate for post-assembly conjugation employing well established conjugation methods.

It has been observed that the incorporation of a sulfhydryl group in ethylene diamine moiety of PNA backbone $(\gamma$ position) did not substantially affect the hybridization properties with complementary RNA. However, the conjugation of the sulfhydryl group at $\gamma$-position leads to the steric destabilization of the PNA-DNA/RNA hybrid. Hence, in this paper we have focused on the synthesis of two thiol-modified $\alpha$-monomers.

\section{Conclusion}

Orthogonally protected novel thiol-modified PNA monomers $\mathbf{9}$ and $\mathbf{1 0}$ were prepared containing thymine and cytosine nucleobases. In this report, the thiol modification is carried out in side chain instead of ligation site, i.e. main ethylene diamine backbone. These novel $\alpha$-monomers would be of relevance in studying hybridization properties and a valuable asset for future conjugation of PNAs with a variety of ligands such as artificial RNA-nucleases for the sequence selective degradation of the target RNA.

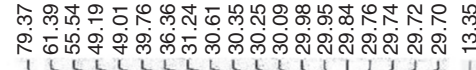

4

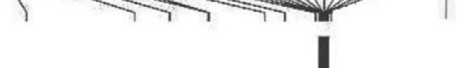

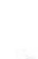

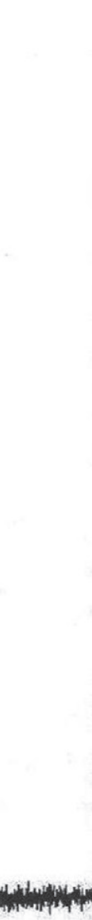

$\begin{array}{llllll}1 & 1 & 1 & 1 & 1 & \\ 80 & 60 & 40 & 20 & 0 & \mathrm{ppm}\end{array}$

minoethylamino]-3-(4-methoxybenzylsulfanyl)-propionic acid (9).

\section{Conflict of interest}

The author has no conflicts of interest to declare.

\section{Acknowledgement}

The author gratefully acknowledges the financial assistance from the Science and Engineering Research Board (DST), New Delhi, with Grant No. SB/FT/CS-057/2012. The author also acknowledges Department of Chemistry, University of Delhi for use of facilities.

\section{Appendix A. Supplementary data}

Supplementary data associated with this article can be found, in the online version, at doi:10.1016/j.jart.2017.01.006.

\section{References}

Banack, S. A., Metcalf, J. S., Jiang, L., Craighead, D., Ilag, L. L., \& Cox, P. A. (2012). Cyanobacteria produce N-(2-aminoethyl) glycine, a backbone for peptide nucleic acids which may have been the first genetic molecules for life on earth. PLOS ONE, 7(11), e49043.

De Koning, M. C., Filippov, D. V., Meeuwenoord, N., Overhand, M., Van der Marel, G. A., \& Van Boom, J. H. (2002). An approach to the synthesis of peptide-PNA-peptide conjugates via native ligation. Tetrahedron Letters, 43(45), 8173-8176. 
De Koning, M. C., Filippov, D. V., Van der Marel, G. A., Van Boom, J. H., \& Overhand, M. (2003). Synthesis of macrocyclic peptide nucleic acid derivatives via intramolecular chemical ligation. Tetrahedron Letters, 44(41), 7597-7600.

De Koning, M. C., Filippov, D. V., Van der Marel, G. A., Van Boom, J. H., \& Overhand, M. (2004). Synthesis of peptide-PNA-peptide conjugates by semi-solid-phase chemical ligation combined with deactivation/capture of excess reactants. European Journal of Organic Chemistry, 2004(4), $850-857$.

De Koning, M. C., Petersen, L., Weterings, J. J., Overhand, M., Van der Marel, G. A., \& Filippov, D. V. (2006). Synthesis of thiol-modified peptide nucleic acids designed for post-assembly conjugation reactions. Tetrahedron, 62(14), 3248-3258.

De Koning, M. C., Van Der Marel, G. A., \& Overhand, M. (2003). Synthetic developments towards PNA-peptide conjugates. Current Opinion in Chemical Biology, 7(6), 734-740.

Dose, C., \& Seitz, O. (2005). Convergent synthesis of peptide nucleic acids by native chemical ligation. Organic Letters, 7(20), 4365-4368.

Dueholm, K. L., Egholm, M., Behrens, C., Christensen, L., Hansen, H. F., Vulpius, T., ..., \& Buchardt, O. (1994). Synthesis of peptide nucleic acid monomers containing the four natural nucleobases: thymine, cytosine, adenine, and guanine and their oligomerization. Journal of Organic Chemistry, 59(19), 5767-5773.

Egholm, M., Buchardt, O., Christensen, L., Behrens, C., Freier, S. M., Driver, D. A., ..., \& Nielsen, P. E. (1993). PNA hybridizes to complementary oligonucleotides obeying the Watson-Crick hydrogen-bonding rules. Nature, 365(6446), 566-568.

Goodwin, T. E., Holland, R. D., Lay, J. O., \& Raney, K. D. (1998). A simple procedure for solid-phase synthesis of peptide nucleic acids with $\mathrm{N}$-terminal cysteine. Bioorganic \& Medicinal Chemistry Letters, 8(16), 2231-2234.

Liu, X., \& Balasubramanian, S. (2000). Strategies for the synthesis of fluorescently labelled PNA. Tetrahedron Letters, 41(32), 6153-6156.

Nielsen, P. E., Egholm, M., Berg, R. H., \& Buchardt, O. (1991). Sequence-selective recognition of DNA by strand displacement with a thymine-substituted polyamide. Science, 254, 1497-1500.

Richter, L. S., Marsters, J. C., \& Gadek, T. R. (1994). Two new procedures for the introduction of benzyl-type protecting groups for thiols. Tetrahedron Letters, 35(11), 1631-1634. 